・论坛・ 中国国家公园试点专题

\title{
海南热带雨林国家公园试点经验
}

\author{
龙文兴 ${ }^{1,2 *}$, 杜彦君 ${ }^{11,2}$, 洪小江 ${ }^{3}$, 㶓润国 ${ }^{4,2}$, 杨琪 $^{3}$, 薛荟 $^{3}$
}

1. 海南大学林学院, 海口 570228; 2. 海南国家公园研究院, 海口 570100; 3. 海南热带雨林国家公园管理局, 海口 570100; 4. 中国林业科 学研究院森林生态环境与保护研究所, 北京 100091

龙文兴, 杜彦君, 洪小江, 藏润国, 杨琪, 薛荟 (2021) 海南热带雨林国家公园试点经验. 生物多样性, 29, 328-330. doi: 10.17520/biods.2021071. Long WX, Du YJ, Hong XJ, Zang RG, Yang Q, Xue H (2021) The experiences of Hainan Tropical Rainforest National Park pilot. Biodiversity Science, 29, 328-330. doi: 10.17520/biods.2021071.

\section{The experiences of Hainan Tropical Rainforest National Park pilot}

\author{
Wenxing Long ${ }^{\left(1,2^{*}\right.}$, Yanjun Du ${ }^{(1,2}$, Xiaojiang Hong ${ }^{3}$, Runguo Zang ${ }^{4,2}$, Qi Yang ${ }^{3}$, Hui Xue ${ }^{3}$ \\ 1 College of Forestry, Hainan University, Haikou 570228 \\ 2 Institute of Hainan National Park, Haikou 570100 \\ 3 Administration of Hainan Tropical Rainforest National Park, Haikou 570100 \\ 4 Institute of Forest Ecology, Environment and Protection, Chinese Academy of Forestry, Beijing 100091
}

海南热带雨林国家公园是目前最晚启动的国 家公园体制试点, 其诞生和推动一直受到高度重 视。2018年4月13日, 习近平总书记在庆祝海南建省 办经济特区30周年大会上发表重要讲话强调, “要 积极开展国家公园体制试点, 建设热带雨林等国家 公园，构建归属清晰、权责明确、监管有效的自然 保护地体系”。海南省委省政府把建设热带雨林国 家公园确定为海南全面深化改革开放的12个先导 性项目之一和建设国家公园生态文明试验区的三 大标志之首。海南热带雨林国家公园体制试点区范 围涉及海南省中部 9 个市县, 包括五指山、鹦哥岭、 尖峰岭、霸王岭、吊罗山 5 个国家级自然保护区、3 个省级自然保护区、4 个国家森林公园、6个省级森 林公园及相关的国有林场, 总面积 $4,403 \mathrm{~km}^{2}$, 约占 海南岛陆域面积的 $1 / 7$ 。试点区立足保护和修复海南 热带雨林生态系统, 充分考虑海南长臂猿 (Nomascus hainanus)等重要物种保护和繁衍的需 要。自2018年开展国家公园试点以来, 海南热带雨 林国家公园紧紧围绕“理顺管理体制、创新运营机 制、健全支撑保障、强化监督管理、构建统一规范
高效的中国特色国家公园体制”试点任务，把体制 机制集成创新摆在首要位置, 创新探索中国特色国 家公园管理海南模式。

\section{1 首创扁平化的国家公园管理体制和双重 国家公园综合执法管理机制}

(1)按照机构改革和《海南热带雨林国家公园总 体规划(2019-2025年)》要求, 结合海南实际, 本着 减少管理层级、提高管理效率的原则，试点区构建 了具有海南特色的扁平化的海南热带雨林国家公 园“管理局-管理分局”二级行政管理体系。一是建立 了省级管理机构。在海南省林业局加挂海南热带雨 林国家公园管理局牌子, 作为海南热带雨林国家公 园管理机构, 增设海南热带雨林国家公园处和森林 防火处两个内设机构。同时在自然保护地管理处加 挂执法监督处、林业改革发展处加挂特许经营和社 会参与管理处牌子, 成立了海南智慧雨林中心并加 挂海南热带雨林国家公园宣教科普中心牌子。二是 整合成立二级管理机构, 海南热带雨林国家公园管 理局下设尖峰岭、霸王岭、吊罗山、黎母山、鹦哥

收稿日期: 2021-03-01; 接受日期: 2021-03-10

基金项目: 国家自然科学基金(31870508; 31660163)和科技基础专项(2019FY101607)

* 通讯作者 Author for correspondence. E-mail: oklong@hainanu.edu.cn 
岭、五指山和毛瑞等7个分局, 作为海南热带雨林国 家公园二级管理机构, 试点区内原有的林业局、保 护区管理局(站)、林场等机构同时撤销。使热带雨 林国家公园“范围上一个整体, 运行上一套班子, 管理上一个标准”, 确保机构扁平高效。

(2)开展国家公园范围内的资源环境综合执法。 试点区独创国家公园综合执法派驻双重管理机制, 明确了国家公园综合执法主体, 建立了热带雨林国 家公园稳定的综合执法队伍, 确保了国家公园范围 内综合行政执法不出现空档。海南热带雨林国家公 园管理局设置了执法监督处，牵头负责指导、监督、 协调国家公园区域内综合行政执法工作; 国家公园 区域内其余行政执法职责实行属地综合行政执法， 由试点区涉及的 9 个市县综合行政执法局承担，单 独设立国家公园执法大队, 分别派驻到国家公园各 分局，由各市县人民政府授权国家公园各分局指挥， 统一负责国家公园区域内的综合行政执法。

\section{创新生态搬迁集体土地与国有土地置换新}

海南热带雨林集中分布的区域是海南岛主要 江河源头和重要水源涵养区, 是黎、苗少数民族传 统栖居地。当地群众生产生活主要依赖自然资源的 传统利用方式与生态保护和经济发展、民生改善的 矛盾突出。试点区探索国家公园核心保护区生态搬 迁，健全生态保护补偿制度，结合脱贫攻坚、乡村 振兴等工作, 促进当地脱贫, 走出生态优先、绿色 发展的路子(王琪, 2020)。

(1)创新土地权属转化方式。海南热带雨林国家 公园生态搬迁过程中, 以自然村为单位, 实行迁出 地与迁入地的土地所有权置换, 迁出地原农民集体 所有的土地全部转为国家所有, 迁入地原国有土地 全部确定为农民集体所有。置换双方权属为集体和 国有，土地性质为建设用地和非建设用地。

(2)建立集体和国有土地置换评估方式。在实施 置换前, 由政府组织开展拟置换土地(迁入地和迁 出地) 的土地现状调查并进行实地踏勘, 摸清土地 权属、地类、面积以及地上青苗和附着物权属、种 类、数量等情况, 市县自然资源和规划部门委托有 资质的第三方评估机构按照相关估价规程开展土 地价值评估, 经集体决策合理确定拟置换的土地地 块价值。

(3)赋权所有权人权能。市县政府将拟置换的土
地现状、置换方式、安置方式等内容进行公告公示, 充分尊重生态搬迁涉及的农民集体、农民和相关土 地权利人的意愿。完整置换迁入地和迁出地权属, 办理不动产产权登记，赋权政府、迁出地集体、迁 入地集体(农垦)三方的权能。迁入地用地原属于集 体土地的, 政府依法办理土地征收审批手续后进行 置换; 迁入地用地原属于国有土地的，市县政府依 法收回国有土地后进行置换或者与农垦国有土地 使用权人直接协商置换，保障迁入地原所有权人的 权利。

(4)建立土地增减挂钩模式。迁出地建设用地复 垦为林地等农用地腾出的建设用地指标, 可按照建 设用地增减挂钩的原则用于迁入地安置区建设, 不 再另行办理农用地转用审批手续。有效地解决了搬 迁土地处置难题，实现“搬得出、稳得住、能发展、 可致富”的生态搬迁目标。

\section{3 建设以核心保护区电子围栏为标志的智 公园}

建设智慧国家公园旨在不增加甚至减少管理 管护人员的情况下，通过加强信息化基础设施，最 大程度减少人为活动(含林业巡护人员)对海南热带 雨林国家公园特别是核心区的干扰，实行最严格的 生态环境保护(陈䂀, 2019)。2019年, 试点区开展了 电子围栏和野生动物监测试点, 通过布设振动光 纤、仿生树和电子雷达技术, 结合主要交叉路口补 点智能卡口和视频监控系统的方式建设电子围栏, 实现人为活动监管和野生动物活动监测。针对雨林 边界的不同环境和位置，采取不同的电子围栏监测 技术。

试点区通过总结试点项目经验，提出了建设 “智慧雨林项目”, 纵向打通省局一分局-护林点-巡 护员，横向打通林业-省级各部门，实现将林区监 测图像画面数据、感应探头数据、气象环境数据、 联网野保相机数据以及道路卡口车辆人员信息数 据传输到省局并进一步共享到各厅局, 将大力提高 热带雨林国家公园资源监管水平和生态管理能力。

\section{4 打造国际科研合作平台和海南长臂猿联 新机制}

由海南热带雨林国家公园管理局联合中国林 业科学研究院、北京林业大学、海南大学、中国热 
带农业科学院共同组建海南国家公园研究院, 在海 南登记为事业单位法人。研究院实行理事会领导下 的执行院长负责制; 人员管理实行市场化的运作方 式，薪酬机制、用人机制、激励机制和市场化接轨。 研究院以项目为导向, 柔性引进高层次及特需人才, 与世界自然保护联盟、世界自然基金会等国际机构 开展广泛合作，建立伙伴关系。

海南国家公园研究院将热带雨林旗舰物种海 南长臂猿的保护研究作为重要任务。向国家林业和 草原局申请获批“国家林草局海南长臂猿保护研究 中心”和 “海南长臂猿保护国家长期科研基地”; 开 展海南长臂猿保护研究全球联合攻关, 制定并实施 科研项目方案，面向全球招募科研项目负责人; 多 次召开海南长臂猿保护国际研讨会, 在国内外相关 领域产生了积极影响; 组织开展海南长臂猿大调查, 全面系统了解海南长臂猿种群和栖息地的基本情 况, 为制定更加科学、有效的海南长臂猿保护研究 方案奠定基础。

\section{5 建立跨部门多层次的监测平台}

热带雨林生态系统是地球上生物多样性最丰 富的生态系统, 具有地球上最丰富的物种数量和生 物生产力, 有着十分特殊的价值和意义。在国家和 海南省林业部门的支持下, 海南大学、中国林业科 学研究院等单位陆续建立了热带雨林生态系统、生 物多样性及动植物种群监测平台。依托中国森林生 态系统定位研究网络, 试点区在五指山、尖峰岭、 霸王岭建立了森林生态系统定位观测研究站, 为热 带雨林生态系统功能评估提供有力支撑; 创建了世 界上首套大样地 + 公里网格样地 + 卫星样地 + 随机样地相结合的四位一体森林动态监测系统, 解 决了热带雨林和生物多样性长时间尺度观测难、复
杂生境中生物多样性比较难、不同空间尺度生态过 程理解难等难题，为热带天然林生物多样性保育及 恢复研究、动态监测、成效评估等提供技术平台。

海南热带雨林国家公园试点区构建了以“省部 协间、多级联动”的协同管理机制、“垂直管理、执 法派驻”的监管体制、“科研平台、全球智库”的科技 支撑体系为主要特色的管理体制和运营机制，这些 集成创新的先进经验都具备广泛推广性。其中创新 生态搬迁集体土地与国有土地置换新模式、创新设 立海南国家公园研究院、建设以核心保护区电子围 栏为标志的智慧国家公园等特色和创新点, 在2019 年12月召开的中国国家公园体制试点工作会议和 国家林业和草原局2020年第一季度例行新闻发布 会上被国家林业和草原局肯定，特别是创新生态搬 迁集体土地与国有土地置换的新模式得到党中央 国务院肯定。

\section{ORCID}

龙文兴 (1D) https://orcid.org/0000-0002-9195-5878

杜彦君 (iD https://orcid.org/0000-0002-7311-0265

\section{参考文献}

Chen X (2019) Problems and countermeasures in the management mode of Hainan National Park System pilot construction. Hainan Today, (1), 63-64. (in Chinese) [陈䂀 (2019) 海南国家公园体制试点建设管理模式难点问题与 对策. 今日海南, (1), 63-64.]

Wang Q (2020) Smoothly progressing of the Three-River source and Hainan Tropical Rain Forest National Park System pilot. Land Greening, (1), 48-49. (in Chinese) [王琪 (2020) 三江源、海南热带雨林国家公园体制试点有序推 进. 国土绿化, (1), 48-49.]

(责任编委：徐卫华 责任编辑：黄祥忠) 